\title{
Introduction for special issue: Carbon, water and nutrient cycling in managed forests
}

A. Noormets ${ }^{1}$ and $Y$. Nouvellon ${ }^{2}$

North Carolina State University, Department of Forestry and Environmental Resources, Campus Box 7260, Raleigh, NC 27695, USA 2 CIRAD, UMR Eco \& Sols, 2 Place Viala, 34060 Montpellier, France

The current special issue represents and builds on the work that was presented in a session by the same name at the AGU Fall Meeting in 2013.

\section{Background}

As the intensity and true expanse of the effect of human activities on forests comes to ever sharper focus (Hansen et al., 2013), so does recognition that the functioning of these affected forests may differ from unperturbed ones in important ways. In fact, our estimates of global carbon, water and nutrient budgets may depend on how well we can explain and attribute observed responses of forest ecosystems to various disturbances and environmental forcing. Birdsey and Pan (2015) review in the current issue the ways and extent to which forests have changed over recent decades and summarize the expected implications for global carbon stocks. Although direct effects through forest management activities are only one and, as of now, still spatially limited (7\% of global forest area; FAO, 2010) mode of human influence on forest function, forests cultivated for timber and wood products production represent a significant point on the spectrum, and offer some insight to how land surface processes may change as human demands on these ecosystems increase (Fig. 1).

Although studies of specific management activities, including fertilization regime, genotypes and species, site preparation and competition control have been the staple of industrial field trials for decades, the effect of these changes to ecosystem-level processes and land-atmosphere interactions has typically not been in the focus. Explicit comparisons of management effects through paired sites are rare (but see Herbst et al., 2015 in current issue). More often extrapolations are based on land use gradients (Domec et al., 2015). Consequently, the differences in the biogeochemical functioning of forests with contrasting management status are not very well understood. The first assessments suggest that the structural differences associated with management may also explain many functional differences (Herbst et al., 2015; Noormets et al., 2015; Fig. 2, 3). That being said, there remain large uncertainties and inconsistencies how human activities, including management, are documented in different databases. Several of the papers included in this issue raised this concern (Birdsey and Pan, 2015; Foote et al., 2015; Masek et al., 2015; Noormets et al., 2015). Thus, for faster progress in attributing management effects and understanding their interactions with environmental factors and biological agents, standardized metadata types will need to be developed and included with major databases. Two recent studies have recently called attention to problems in interpreting global carbon balance estimates that can be traced to the lack of consistent terminology about land use history, including management activities (Houghton, 2013; 
Pongratz et al., 2014). Standardization and universal classification across databases would facilitate faster transfer of knowledge from case studies and site-based parameterization in models (Gonzalez-Benecke et al., 2015; Templeton et al., 2015; Tian et al., 2015) to regional and global scales (Masek et al., 2015).

\section{Key findings}

Among the papers in the current special issue, two common themes emerged: (i) the contribution of active forest management to drought tolerance, including the interaction between water and nutrient availabilities, environmental factors and biotic agents (Domec et al., 2015; Law and Waring, 2015; Ward et al., 2015), and (ii) the potential trade-off between biomass production and long-term carbon sequestration (Birdsey and Pan, 2015; Foote et al., 2015; Law and Waring, 2015; Noormets et al., 2015). As future climate projections forecast greater variability in rainfall and longer, more pronounced droughts, forests are expected to suffer more from both the direct effect of water limitation, as well as indirect, drought-stressrelated pest outbreaks and mortality. In particular, the greater water needs and lower root area of fast-growing plantation species (Noormets et al., 2015) will likely result in narrower safety margin to handle stress events (Domec et al., 2015), especially in heavily fertilized plantations (White et al., 2009; Battie-Laclau et al., 2014). Safety margins are also likely to decrease with increasing stand density (McDowell and Allen, 2015). The sustainability of fast-growing plantations may also be compromised when the large amounts of nutrients removed with biomass at the end of the rotations are not compensated by nutrient inputs through fertilization, atmospheric deposition, or nitrogen biological fixation (Laclau et al., 2010). These findings highlight the need to re-evaluate the optimization models that guide our assessment of environmental risk factors and the economic costs and benefits of wood production. In this issue, several authors emphasized the significance of interactions between management, environmental and biological factors (Foote et al., 2015; Law and Waring, 2015; Vogel et al., 2015; Ward et al., 2015), which all affect biomass allocation, and thus exposure and sensitivity to different stresses. Law and Waring (2015) also emphasized the significance of political context that can either facilitate or undo both biological and management processes.

In addition to affecting root area and access to water resources, changing allocation patterns (especially belowground) in response to environmental and management stimuli also has implications for soil C input, microbial activity, and long-term C sequestration (Fig. 4). Although belowground $C$ inputs increase with overall productivity, the proportional allocation varies as a function of different environmental constraints and stand characteristics (Chen et al., 2013), and the expected correlations between allocation and pool size may not always be detectable due to time lags and disturbance effects (Vogel et al., 2015). In the current volume, four studies report evidence suggesting a trade-off between productivity and carbon sequestration (Birdsey and Pan, 2015; Foote et al., 2015; Law and Waring, 2015; Noormets et al., 2015). Although these two fluxes are correlated and functionally related, equating them as sometimes mistakenly is done, leads to overestimating the climate mitigation potential of forests. Quantifying belowground carbon pools and fluxes, and understanding their dynamics under changing environmental and management forcing remains a topic of large uncertainties. Reducing these will be possible by considering processes integrated over the entire life (or rotation) cycle of the forest (Noormets et al., 2012; Nouvellon et al., 2012), which is easier done 
in short-lived plantations than in natural forests. Forests contain large amount of carbon in both plant and soil pools, and their use in climate mitigation must strive to conditions that maximize both. Birdsey and Pan (2015) report that the area of forests managed for non-timber products has risen significantly in recent decades. The full implications of this are not clear at this point, although some forfeiting of biological and economic productivity may be required. Four studies in the current issue suggest extended rotation cycles that would help minimize the disturbancedriven losses through heterotrophic respiration (Birdsey and Pan, 2015; Foote et al., 2015; Law and Waring, 2015; Noormets et al., 2015). Increasing the rotation length would also increase the biomass carbon stock (Gonzalez-Benecke et al., 2015), averaged over stands of different ages that typically constitute managed forest areas (Fig. 1). An assessment of the full potential of this, and other potential changes to management activities to balance economic productivity with other ecosystem services such as carbon sequestration, sustaining soil health and water resources, is urgently needed. As illustrated in three studies (Birdsey and Pan, 2015; Law and Waring, 2015; Noormets et al., 2015), there are costs to pursuing different management goals, but no ready tools to evaluate the tradeoffs.

\section{Vision of the future}

Taken together, these recent studies dealing with the carbon, water and nutrient cycling in forest ecosystems suggest that managed forests may become more vulnerable to environmental and biological stresses (McNulty et al., 2014; Law and Waring, 2015; McDowell and Allen, 2015), and that balancing this risk requires compromises in economic productivity. As suggested by Birdsey and Pan (2015), these demands may lead to further specialization in forest management, whereby the productivity (and the intensity of management) may continue to grow on elite lands, whereas managing for non-timber products may prove optimal on more marginal lands. To capture the biogeochemical dynamics of forests along the management spectrum with different structural and functional traits (Noormets et al., 2015), and quantify their contribution to the regional exchange, the next generation earth system models include capability for species-specific parameterizations (Pavlick et al., 2013), using both in situ and remotely sensed observations (Law and Waring, 2015; Masek et al., 2015).

\section{Acknowledgements}

This work was supported by DOE BER-TES awards number 7090112 and 11-DE-SC-0006700, USDA NIFA grant 2011-67009-20089, US Forest Service Eastern Forest Environmental Threat Assessment Center grant 08-JV-11330147-038, and the PINEMAP project. The Pine Integrated Network: Education, Mitigation, and Adaptation project (PINEMAP) is a Coordinated Agricultural Project funded by the USDA National Institute of Food and Agriculture, Award \#2011-68002-30185.

\section{References (page numbers need to be added when known!!!)}

Battie-Laclau, P., Laclau, J.P., Domec, J.C., Christina, M., Bouillet, J.P., de Cassia Piccolo, M., de Moraes Goncalves, J.L., e Moreira, R.M., Krusche, A.V., Bouvet, J.M., Nouvellon, Y., 2014. Effects of potassium and sodium supply on drought-adaptive mechanisms in Eucalyptus grandis plantations. New Phytol 203, 401-413. 
Birdsey, R., Pan, Y., 2015. Trends in management of the world's forests and impacts on carbon stocks. Forest Ecol Manag, In press.

Chen, G., Yang, Y., Robinson, D., 2013. Allocation of gross primary production in forest ecosystems: allometric constraints and environmental responses. New Phytologist 200, 1176-1186.

Domec, J.-C., Ward, E.J., Oishi, A.C., Palmroth, S., Radecki, A., Bell, D.M., Miao, G., Gavazzi, M., Johnson, D.M., King, J.S., McNulty, S.G., Oren, R., Sun, G., Noormets, A., 2015. Conversion of natural forests to managed forest plantations impacts tree response to climatic variable and affects negatively tree resistance to prolonged droughts Forest Ecol Manag, In press.

FAO, 2010. Global Forest Resources Assessment 2010: Progress towards sustainable forest management. Food and Agriculture Organization of the United Nations. Rome. 320 pp. In, Rome, p. 378.

Foote, J.A., Boutton, T.W., Scott, D.A., 2015. Soil C and N storage and microbial biomass in US southern pine forests: Influence of forest management. Forest Ecol Manag, In press.

Gonzalez-Benecke, C.A., Samuelson, L.J., Martin, T.A., Cropper Jr, W.P., Johnsen, K.H., Stokes, T.A., Butnor, J.R., Anderson, P.H., 2015. Modeling the effects of forest management on in situ and ex situ longleaf pine forest carbon stocks. Forest Ecol Manag, In press.

Hansen, M.C., Potapov, P.V., Moore, R., Hancher, M., Turubanova, S.A., Tyukavina, A., Thau, D., Stehman, S.V., Goetz, S.J., Loveland, T.R., Kommareddy, A., Egorov, A., Chini, L., Justice, C.O., Townshend, J.R.G., 2013. High-Resolution Global Maps of $21^{\text {st }}$-Century Forest Cover Change. Science 342, 850-853.

Herbst, M., Mund, M., Tamrakar, R., Knohl, A., 2015. Differences in carbon uptake and water use between a managed and an unmanaged beech forest in central Germany. Forest Ecol Manag, In press.

Houghton, R.A., 2013. Keeping management effects separate from environmental effects in terrestrial carbon accounting. Global Change Biology 19, 2609-2612.

Laclau, J.P., Levillain, J., Deleporte, P., Nzila, J.D., Bouillet, J.P., Saint Andre, L., Versini, A., Mareschal, L., Nouvellon, Y., M'Bou, A.T., Ranger, J., 2010. Organic residue mass at planting is an excellent predictor of tree growth in Eucalyptus plantations established on a sandy tropical soil. Forest Ecol Manag 260, 2148-2159.

Law, B.E., Waring, R.H., 2015. Carbon implications of current and future effects of drought, fire and management on Pacific Northwest forests. Forest Ecol Manag, In press.

Masek, J., Hayes, D., Turner, D., Hughes, M.J., Healey, S., 2015. The role of remote sensing in processscaling studies of managed forest ecosystems. Forest Ecol Manag, In press.

McDowell, N.G., Allen, C.D., 2015. Darcy's law predicts widespread forest mortality under climate warming. Nat Clim Change 5, 669-672.

McNulty, S.G., Boggs, J.L., Sun, G., 2014. The rise of the mediocre forest: why chronically stressed trees may better survive extreme episodic climate variability. New Forests 45, 403-415.

Noormets, A., Epron, D., Domec, J.C., McNulty, S.G., Fox, T.D., Chen, J., Sun, G., King, J.S., 2015. Effects of forest management on productivity and carbon sequestration: a review and hypothesis. Forest Ecol Manag, In press.

Noormets, A., McNulty, S.G., Domec, J.C., Gavazzi, M.J., Sun, G., King, J.S., 2012. The role of harvest residue in rotation cycle carbon balance in loblolly pine plantations. Respiration partitioning approach. Global Change Biology 18, 3186-3201.

Nouvellon, Y., Epron, D., Marsden, C., Kinana, A., Le Maire, G., Deleporte, P., Saint-Andre, L., Bouillet, J.P., Laclau, J.P., 2012. Age-related changes in litter inputs explain annual trends in soil $\mathrm{CO}_{2}$ effluxes over a full Eucalyptus rotation after afforestation of a tropical savannah. Biogeochemistry 111, 515-533. 
Pavlick, R., Drewry, D.T., Bohn, K., Reu, B., Kleidon, A., 2013. The Jena Diversity-Dynamic Global Vegetation Model (JeDi-DGVM): a diverse approach to representing terrestrial biogeography and biogeochemistry based on plant functional trade-offs. Biogeosciences 10, 4137-4177.

Pongratz, J., Reick, C.H., Houghton, R.A., House, J.I., 2014. Terminology as a key uncertainty in net land use and land cover change carbon flux estimates. Earth Syst. Dynam. 5, 177-195.

Templeton, B.S., Seiler, J.R., Peterson, J.A., Tyree, M.C., 2015. Environmental and stand variables influencing soil $\mathrm{CO}_{2}$ efflux across the managed range of loblolly pine. Forest Ecol Manag, In press.

Tian, S., Youssef, M.A., Sun, G., Chescheir, G.M., Noormets, A., Amatya, D.M., Skaggs, R.W., King, J.S., McNulty, S., Gavazzi, M., Miao, G., Domec, J.-C., 2015. Testing DRAINMOD-FOREST for predicting evapotranspiration in a mid-rotation pine plantation. Forest Ecol Manag, In press.

Vogel, J.G., He, D., Jokela, E.J., Hockaday, W., Schuur, E.A.G., 2015. The effect of fertilization levels and genetic deployment on the isotopic signature, constituents, and chemistry of soil organic carbon in managed loblolly pine (Pinus taeda L.) forests. Forest Ecol Manag, In press.

Ward, E.J., Domec, J.C., Laviner, M.A., Fox, T.D., Sun, G., McNulty, S.G., King, J.S., Noormets, A., 2015. Fertilization intensifies drought stress: Water use and stomatal conductance of Pinus taeda in a midrotation fertilization and throughfall reduction experiment. Forest Ecol Manag, In press.

White, D.A., Crombie, D.S., Kinal, J., Battaglia, M., McGrath, J.F., Mendham, D.S., Walker, S.N., 2009. Managing productivity and drought risk in Eucalyptus globulus plantations in south-western Australia. Forest Ecol Manag 259, 33-44.

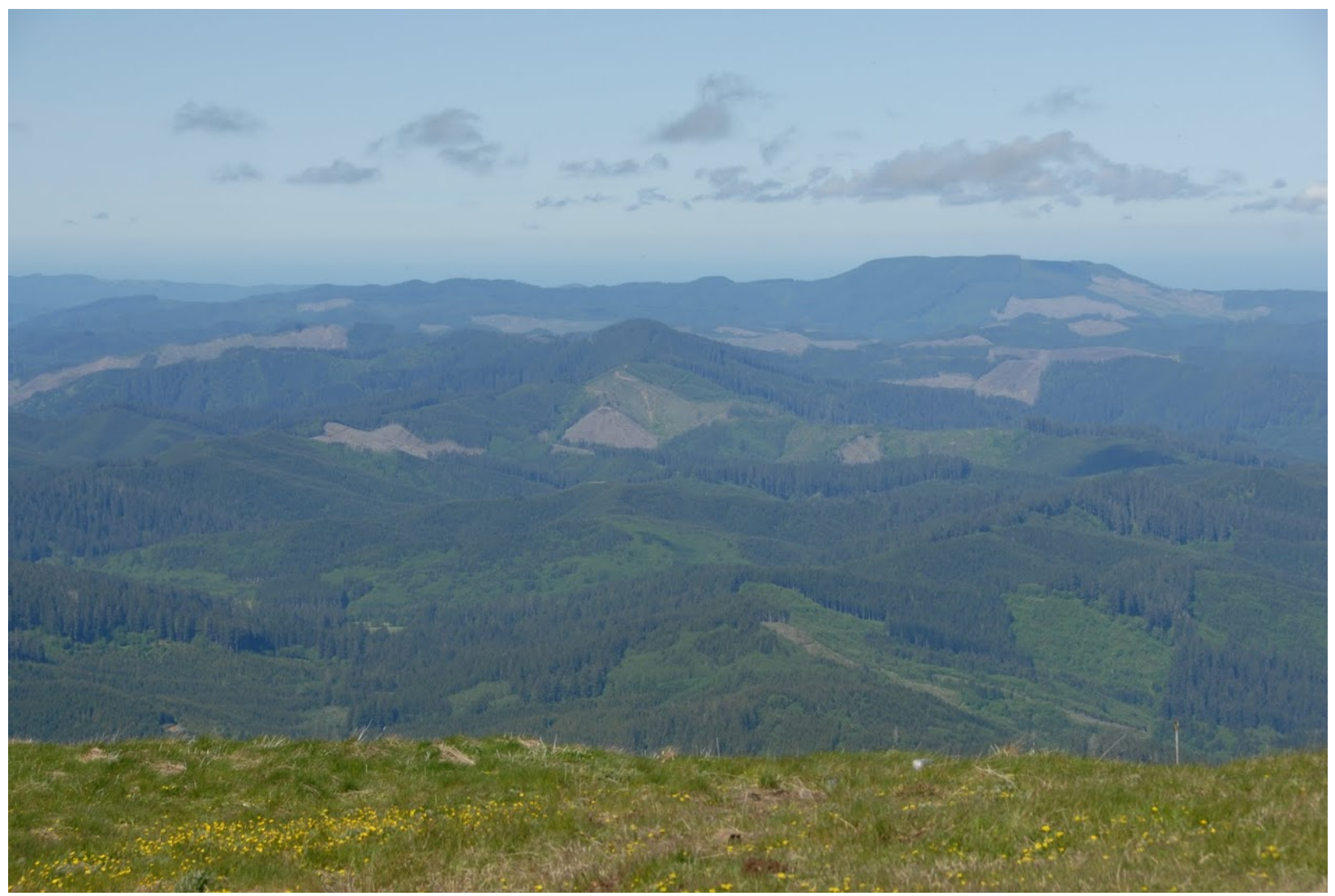

Figure 1. A mosaic of forests of different ages, ownership status and management levels. Mary's Peak, Oregon, USA. Photo by Beverly Law. 

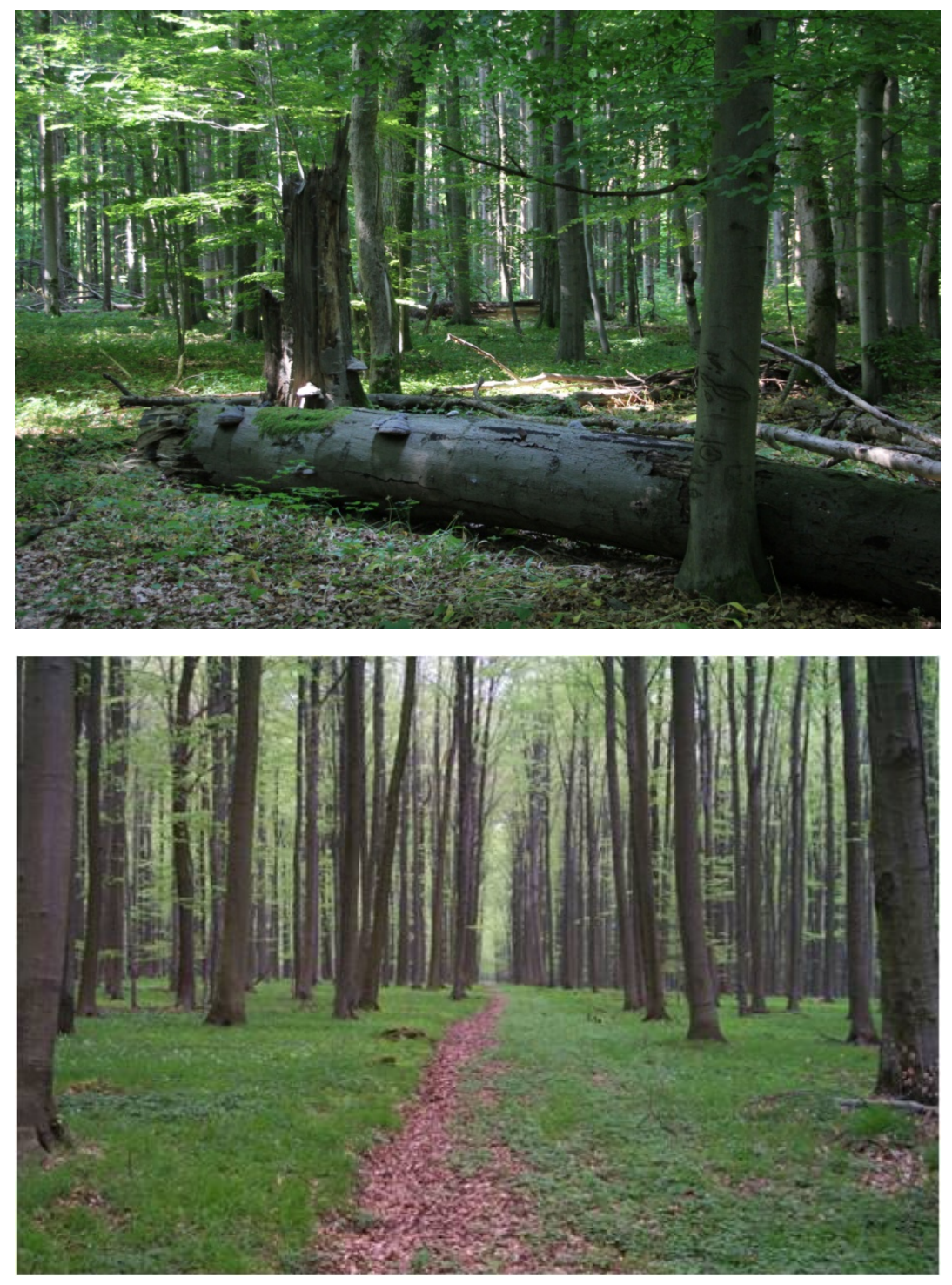

Figure 2. Unmanaged (top, Hainich) and managed (bottom, Leinefelde) beech forests in Thuringia, Germany. Management affects the distribution of carbon between different pools, with implications for fluxes. Photos by Mathias Herbst. 


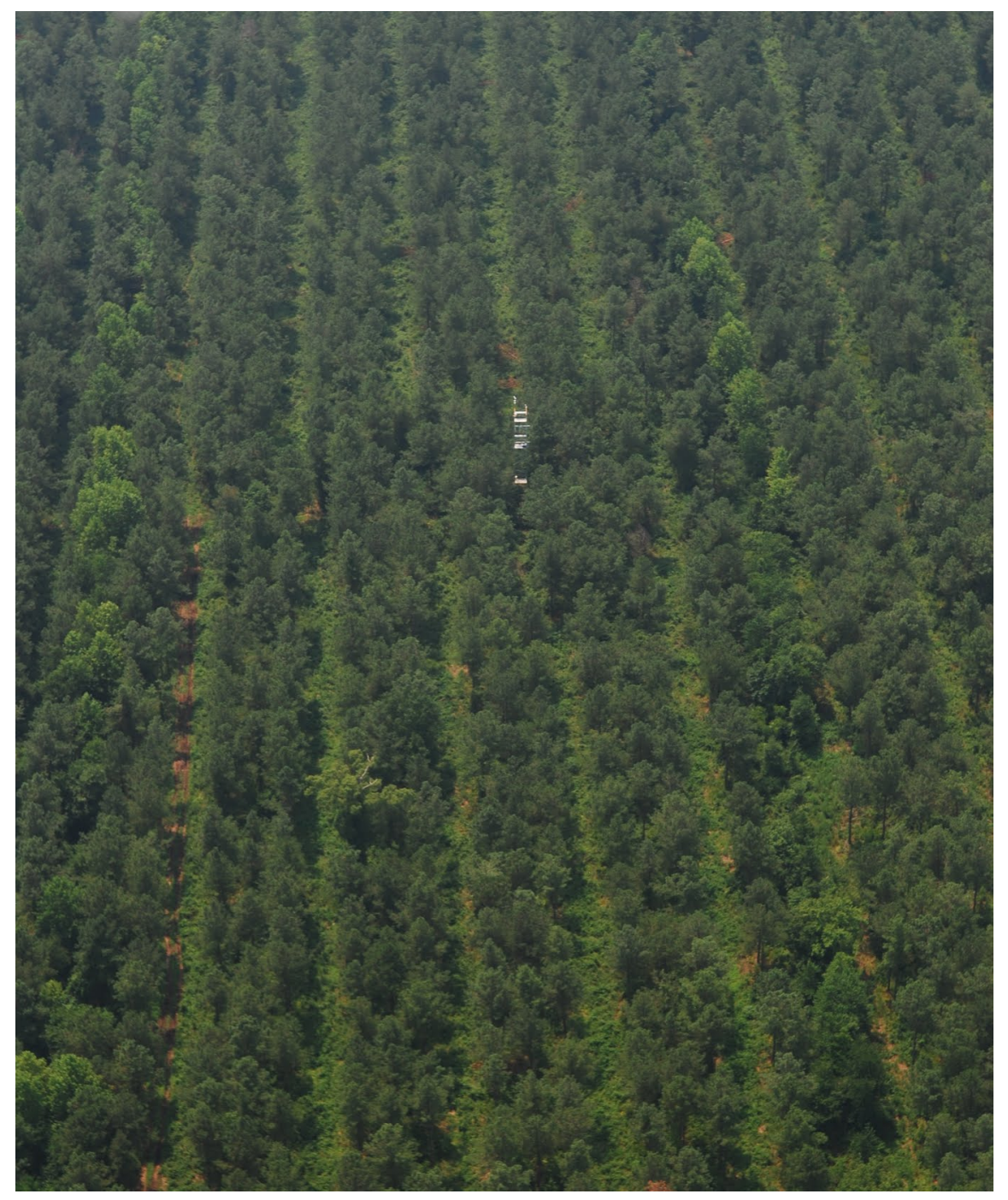

Figure 3. Open canopy structure a year after a thinning operation at the US-NC2 Ameriflux site (lower coastal plain of North Carolina, USA). Gaps left by removing every third row of trees, as well as subdominant trees within remaining rows allow vigorous development of understory, which unlike in a typical commercial setting, was not controlled in this stand. Photo by Bruce Cook. 


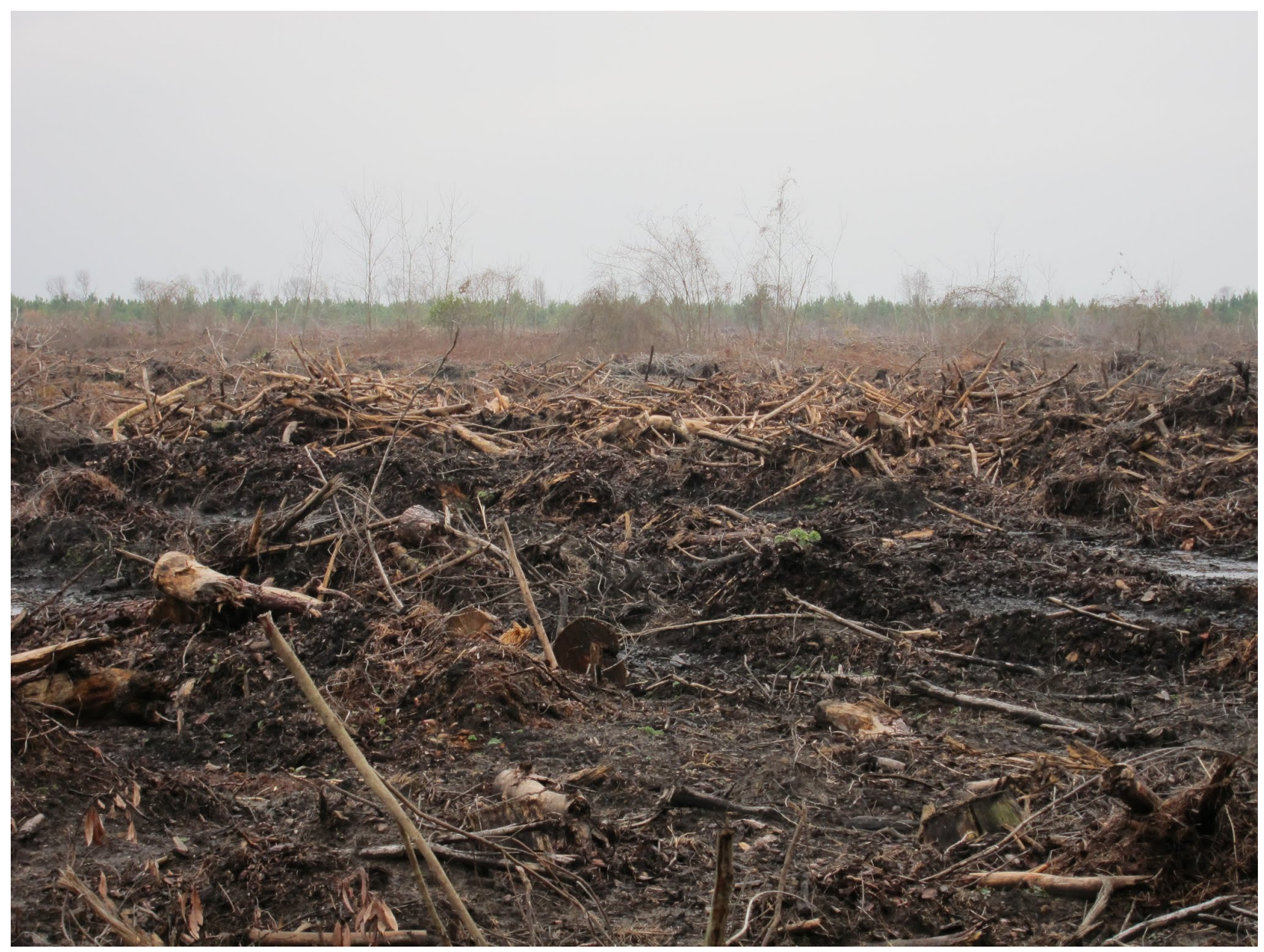

Figure 4. The disturbance from harvest and subsequent site preparation (e.g. bedding) can trigger a substantial pulse of $\mathrm{CO}_{2}$ emissions, lasting for a few years. Long-term sequestration of $\mathrm{C}$ in soils is possible only if carbon inputs to soil over the rotation cycle offset the harvest-related and baseline emissions. US-NC3 Ameriflux site. Photo by Michael Gavazzi. 